\title{
IMPURITY TRANSFER MODEL OF TRANSPORT ORIGIN IN THE STRUCTURE OF THE STREETS-CANYONS OF THE CENTRAL PART OF KHARKOV
}

\author{
Solodov V. G. \\ Kharkov National Automobile and Highway University
}

\begin{abstract}
The work is devoted to the development of a model and the study of the characteristics of the process of transporting pollutants in the surface layer of the quarters of the central part of the city in the presence of plantings and terrain. The micro-district of the central part of the city of Kharkov is considered as the basis of the model. On this basis, the LAWEP approach was applied [17], which consists in preliminary calculation of advection for the general center model on a relatively coarse grid. A linear source is provided along the centerline of the streets, emitting a constant in time consumption of impurities. Methodology. The motion of the air is described by the Navier-Stokes equations averaged by Reynolds. To model turbulent transport effects, the High-Reynolds two-parameter differential turbulence model with wall functions was used as the base one. Modeling of space canopy with leaves and tree branches is carried out on the basis of a porous medium model. The study was carried out using the authors MTFS ${ }^{\circledR}$ software package, with TVD scheme of 2/3 order of accuracy. The Results. Satisfactory agreement with experimental data was obtained. A thermal island phenomenon has been detected. The influence of the structure of canyon streets on the distribution of impurities from vehicles is shown.
\end{abstract}

Key words: structure of canyon streets, stands, surface layer, pollution transfer.

\section{Introduction}

Most of the literature presents examples of modeling the propagation of traces from point sources of contamination on arrays of regular structure [1-19], but the scattering characteristics of a point source in a real urban development may differ significantly from those in regular series of model buildings. In addition, the problem of numerical simulation of various scenarios of pollution of city quarters in order to identify hidden dependencies, trends in the dispersion of impurities in the surface layer, the forecast of some basic parameters of the state of the environment is urgent. Therefore, it is of particular interest to confirm the results of model studies for the case of real city districts containing canyon streets. In this paper, based on the Reynolds-averaged non-stationary NavierStokes equations, we study the model of a real city district.

The work is devoted to modeling the spread of atmospheric pollution in the surface layer of the central part of the city of Kharkiv (City Center). The center (Fig. 2, 3) is a sub-model of the general model of the central part of Kharkiv (Fig. 1). Its construction was based on the city map (https://2gis.ua/kharkov) and the plan of the city surfaces, and covers the space of $5000 \times 5000 \times 300 \mathrm{~m}^{3}$. The overall model of the central part contained several thousand multistorey buildings. The central part is located on a hill and is separated from other parts of the city by a system of rivers from the west, south and east. The terrain of the entire central part of the city has a height difference of about 90 meters. In the south and southwestern parts of the river is a valley, the northwestern part is limited by a large ravine, which passes into the forest, in the northeast there are an airfield and a forest park (Fig. 1). The mesh model of the central part contains about $4 \mathrm{e}+07$ cells and takes into account the description of the boundary layer on the ground surface.

Below, based on the non-stationary NavierStokes equations, the impurity transfers equations, in the approximation of a weakly compressible medium, the propagation in the surface layer of the atmosphere of a trace of a linear impurity source on the example of stationary carbon monoxide (CO) emission along the axial line is investigated. A two-parameter differential turbulence model with wall functions is used to model the turbulent transfer effects. The constants and a detailed description of the model can be found in [19-21]. The influence of vegetation in the square (Fig. 3, № 1) is taken into account by the source terms in the right-hand sides of the momentum equations in the form of a linear dependence $F_{i}=-C_{0} u_{i}$. According to experimental data [14], $C_{0}=1$ is selected for dense summer leaves. According to the recommendation $[14,18,19]$ in the equation of transfer of kinetic energy of turbulence a source type 
member was introduced $F_{k}=u_{i} F_{i}$, into the transfer equation $\varepsilon-$ source member type $F_{\varepsilon}=C_{k} \varepsilon / k F_{k}$. The model interprets the influence of vegetation as a homogeneous isotropic non-inertial volume, with additional terms in the model equations increasing turbulence production.

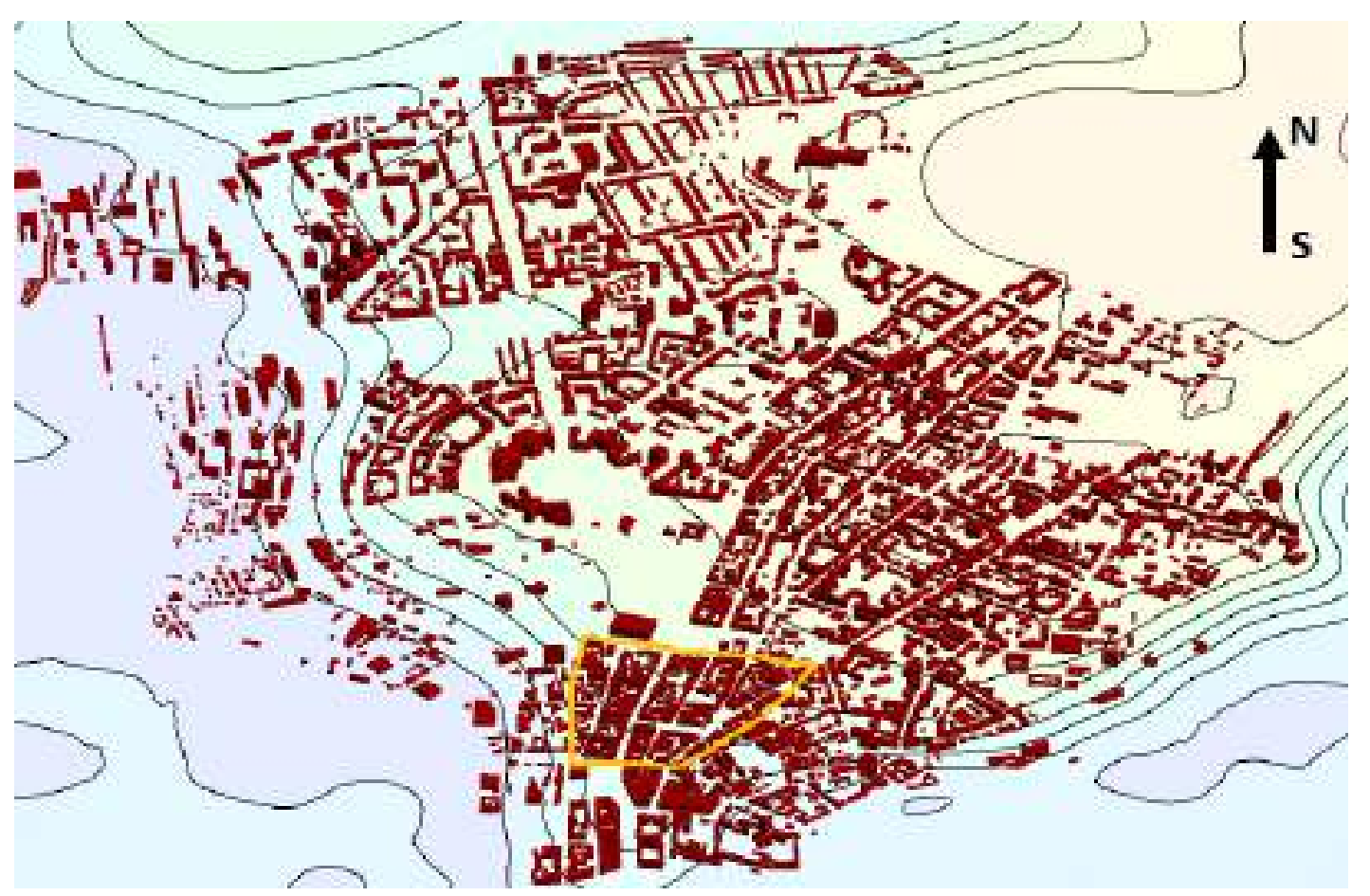

Fig. 1. Model of the central part of Kharkiv with the topography and a submodel

\section{Modeling problem statement}

The study was carried out experimentally by measurements on the ground, as well as by modeling using the author's MTFS ${ }^{\circledR}$ software [15] by the method of setting from the braked state to the developed constant in the middle flow. The flow outside the computational domain of the entire model is assumed completely turbulent. The second stage of the calculation is based on the LAWEPS approach [17], in which the boundary conditions for the sub-model are taken from the calculation of the whole model of the central part of the city. The calculation of the submodel goes on in a non-stationary formulation.

Along the centerline of the main streets (№ 2-6), a linear source was assumed to provide a constant flow of impurity in time and along the road at an altitude of about 0,5 meters with a temperature equal to the flow temperature of the incoming stream. Based on the analysis of the traffic flow and the experimental dependences obtained in the experiments [23], a constant time flow rate of $\mathrm{CO}$ in the form of a mass fraction per linear meter of the centerline of 5e-06 was determined, which corresponded to the experimental data. Streets № 3, 4, 4,6 are central, characterized by heavy traffic. The properties of air and $\mathrm{CO}$ are taken from [22].

An experimental setup. To formulate the simulation problem, experimental measurements of $\mathrm{CO}$ and atmospheric parameters at the submodel points were performed. The state of the atmosphere was estimated during the summer day of the year. A series of experimental measurements of the mass fraction of $\mathrm{CO}$ in the daylight summer hot time, 14-00, was made in the beginning of August 2018 with bright sun and dominating southwest wind (Fig. 4) at a speed of about $2 \mathrm{~m} / \mathrm{s}$ and in the presence of dense leaves in the square. The air temperature was about $33^{\circ} \mathrm{C}$ with the heat flux from solar radiation of $500 \mathrm{~W} / \mathrm{m}^{2}$ selected from the literature $[18$, p. 340]. The walls of the buildings were considered adiabatic.

Measurement points were selected at street crossroads (points 2a, 3a, 4a, 5a, 6, Fig. 3). Experimental measurements of $\mathrm{CO}$ concentration were performed at a height of $1,5 \mathrm{~m}$. The measurements were performed with two experiments at each selected point with a time interval of 30 min between every series. The measurement data are presented in table 1. 


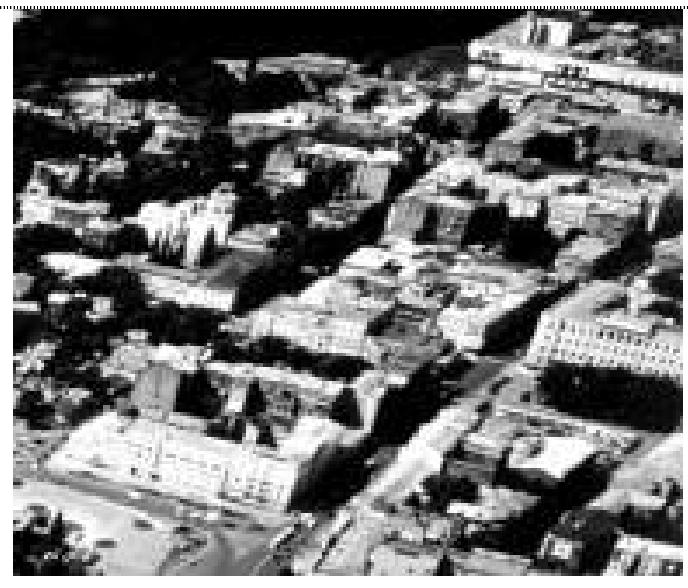

Fig. 2. Aerial photography of a fragment of the building area

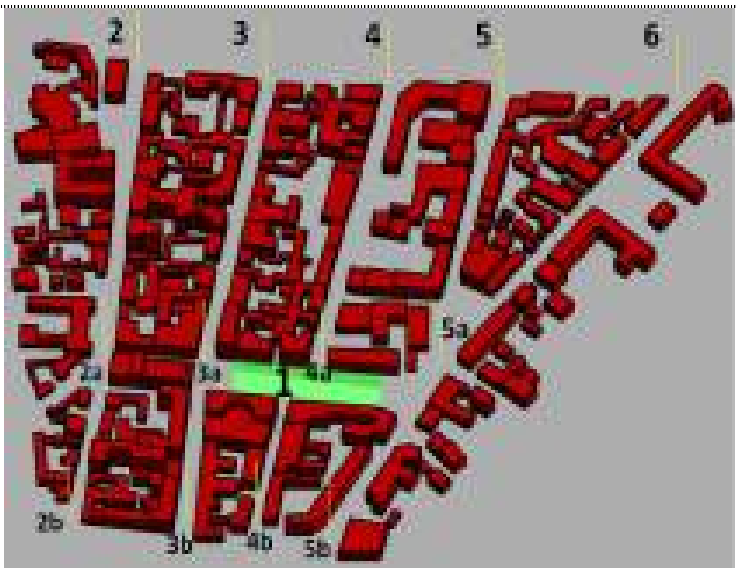

Fig. 3. Scheme of streets measuring the mass fraction of $\mathrm{CO}$ and temperature in the fragment of the development area; № 1-a square with thick leaves; № 2-6- streets; points $2-6,2 \mathrm{a}-5 \mathrm{a}, 2 \mathrm{~b}-5 \mathrm{~b}$-crossroads

Table 1 - Aggregated measurement and calculation results for sites № 2-6

\begin{tabular}{|c|c|c|c|c|c|}
\hline $\begin{array}{c}\text { Area, } \\
\text { measuring } \\
\text { point }\end{array}$ & $\begin{array}{c}\text { Experiment № 1, } \\
\text { mass fraction } \\
\text { CO }\end{array}$ & $\begin{array}{c}\text { Experiment № } \\
\text { 2, mass fraction } \\
\text { CO }\end{array}$ & $\begin{array}{c}\text { Air tempera- } \\
\text { ture, K. }\end{array}$ & $\begin{array}{c}\text { Local wind } \\
\text { velocity, m/s, } \\
\text { direction }\end{array}$ & $\begin{array}{c}\text { Calculation of } \\
\text { mass fraction } \\
\text { of CO }\end{array}$ \\
\hline № 2a & $9.0 \mathrm{e}-6$ & $8.0 \mathrm{e}-6$ & 306 & $0.20(\Pi)$ & $1.1 \mathrm{e}-05$ \\
\hline № 3a & $2.0 \mathrm{e}-6$ & $3.5 \mathrm{e}-6$ & 305 & $0.50(\Pi)$ & $1.4 \mathrm{e}-06$ \\
\hline № 4a & $5.0 \mathrm{e}-7$ & $2.5 \mathrm{e}-6$ & 303 & $0.20(\Pi)$ & $2.5 \mathrm{e}-06$ \\
\hline № 5a & $1.1 \mathrm{e}-6$ & $1.9 \mathrm{e}-6$ & 303 & $0.40(\Pi)$ & $1.7 \mathrm{e}-06$ \\
\hline № 6 & $9.5 \mathrm{e}-7$ & $1.0 \mathrm{e}-6$ & 303 & $0.50(\Pi-3)$ & $1.1 \mathrm{e}-07$ \\
\hline
\end{tabular}

Vehicle exhaust emissions were evaluated individually for each segment of the road on the basis of experimental data as well as traffic intensity data. Namely, the distribution of $\mathrm{CO}$ along the streets was as follows. Each street № $2-6$ is divided into sections $2-6,2 \mathrm{a}-5 \mathrm{a}, 2 \mathrm{~b}-$ $5 \mathrm{~b}$. At each site, an individual cost was set based on experiment data for the southwest wind. The data from the experiments were concentrated. Distribution along the streets was determined by constant law.

All rates were considered constant; wind direction and velocity over the measurement time interval were also considered constant. Next, a non-stationary calculation of the wind flow at constant boundary conditions was performed.

On the obtained from the experiments of the distribution of $\mathrm{CO}$ were also considered computational modeling of the blowing of the terrain and buildings with a southwestern wind (Fig. 4, 5). These data were compared with those for northeast wind (Fig. 6, 7); northwest wind (Fig. 8, 9); southeast wind (Fig. 10, 11).

\section{Discussion the results of the study}

Fig. 4-11 show the distribution of the mass fraction of $\mathrm{CO}$ at a height of $2 \mathrm{~m}$ from the surface of the earth, and the roofs of buildings (at a distance of $0,2 \mathrm{~m}$ ), as components of automobile exhaust at the mean square averaging over a period of 0,5 hours of daytime.

These figures also show the distribution of air temperature near the surface of buildings $(0,2 \mathrm{~m})$ and near the ground, as well as the road surface at elevated atmospheric temperature. Temperature fields, velocity fields, and CO particle distribution fields are non-stationary, so the distribution patterns are obtained by averaging over the integration period at the mean square averaging over a period of 0,5 hours of daytime.

Calculations of heat transfer and impurity were performed for different wind directions at constant velocity magnitude. The spot of high temperature over the fragment of construction, which covers the considered urban development, and corresponds to the presence of a «heat island» at a temperature difference of about 2$4^{\circ} \mathrm{C}$, draws attention. 


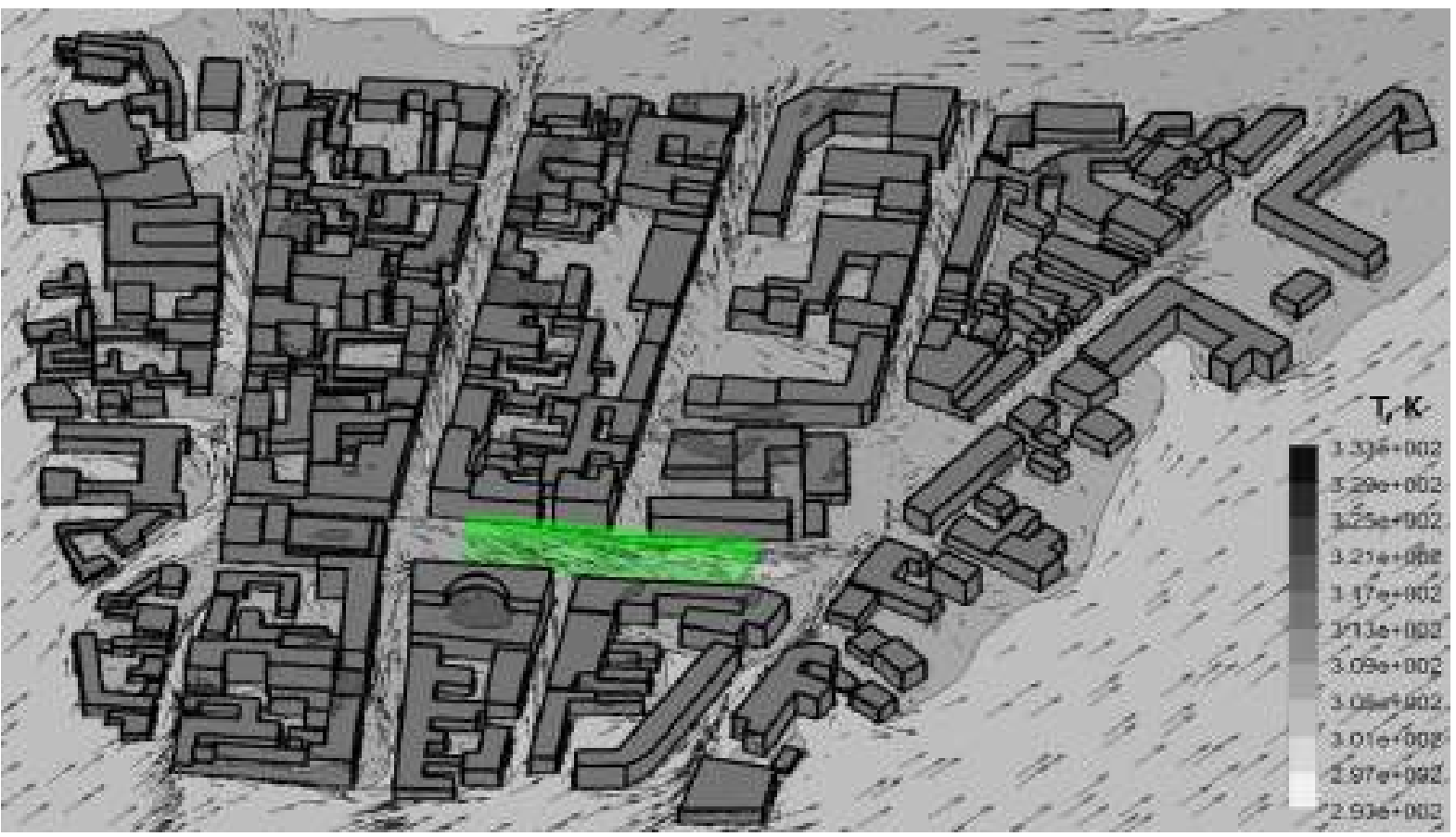

Fig. 4. Distribution of air temperature near the surface of buildings and soil at root mean square averaging over a period of 0,5 hours of daytime at elevated $\mathrm{T}$ of air (southwestern wind)

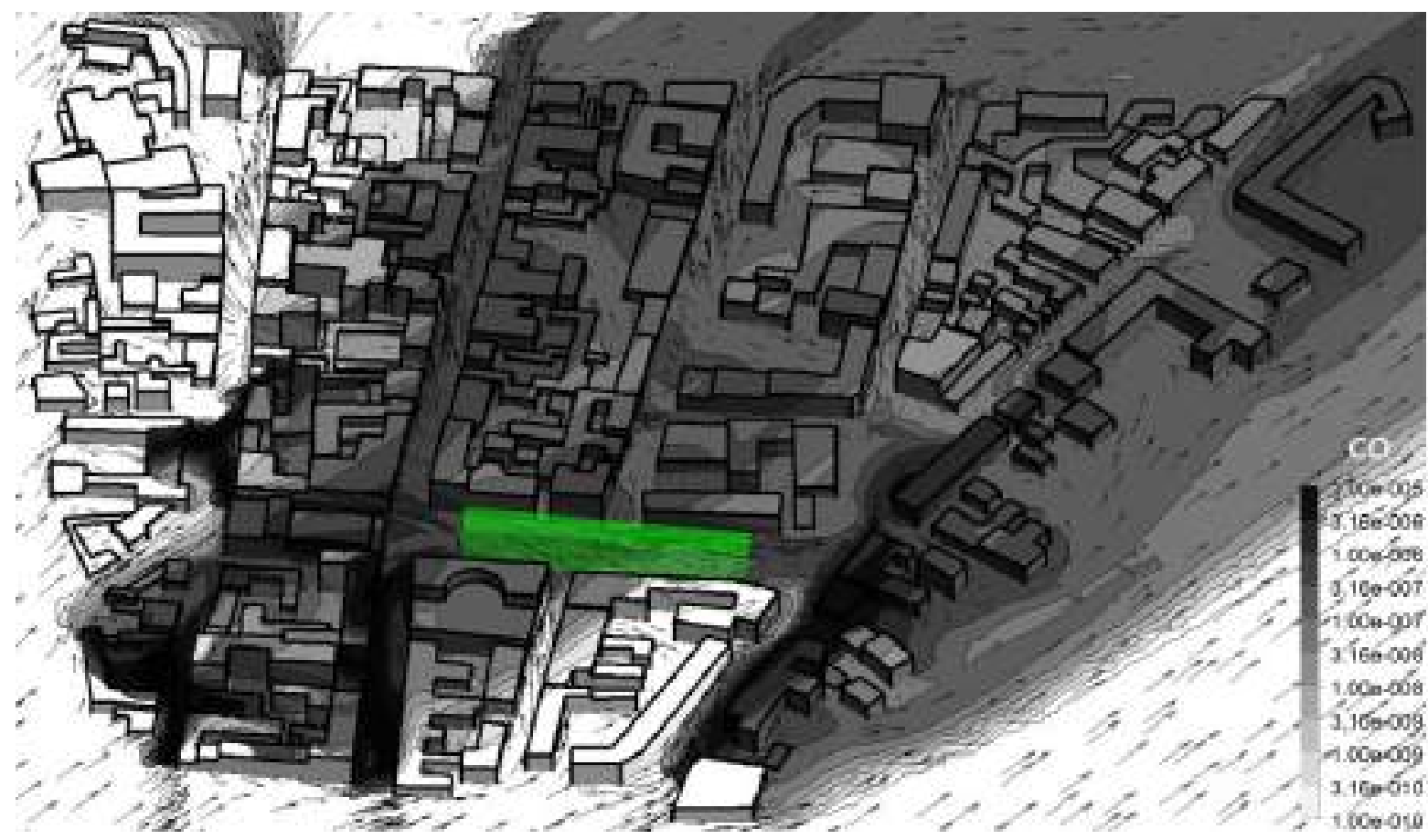

Fig. 5. Distribution of the mass fraction of CO near the surface of buildings and soil at root mean square averaging over a period of 0,5 hours of daytime at elevated $\mathrm{T}$ air (southwestern wind) 


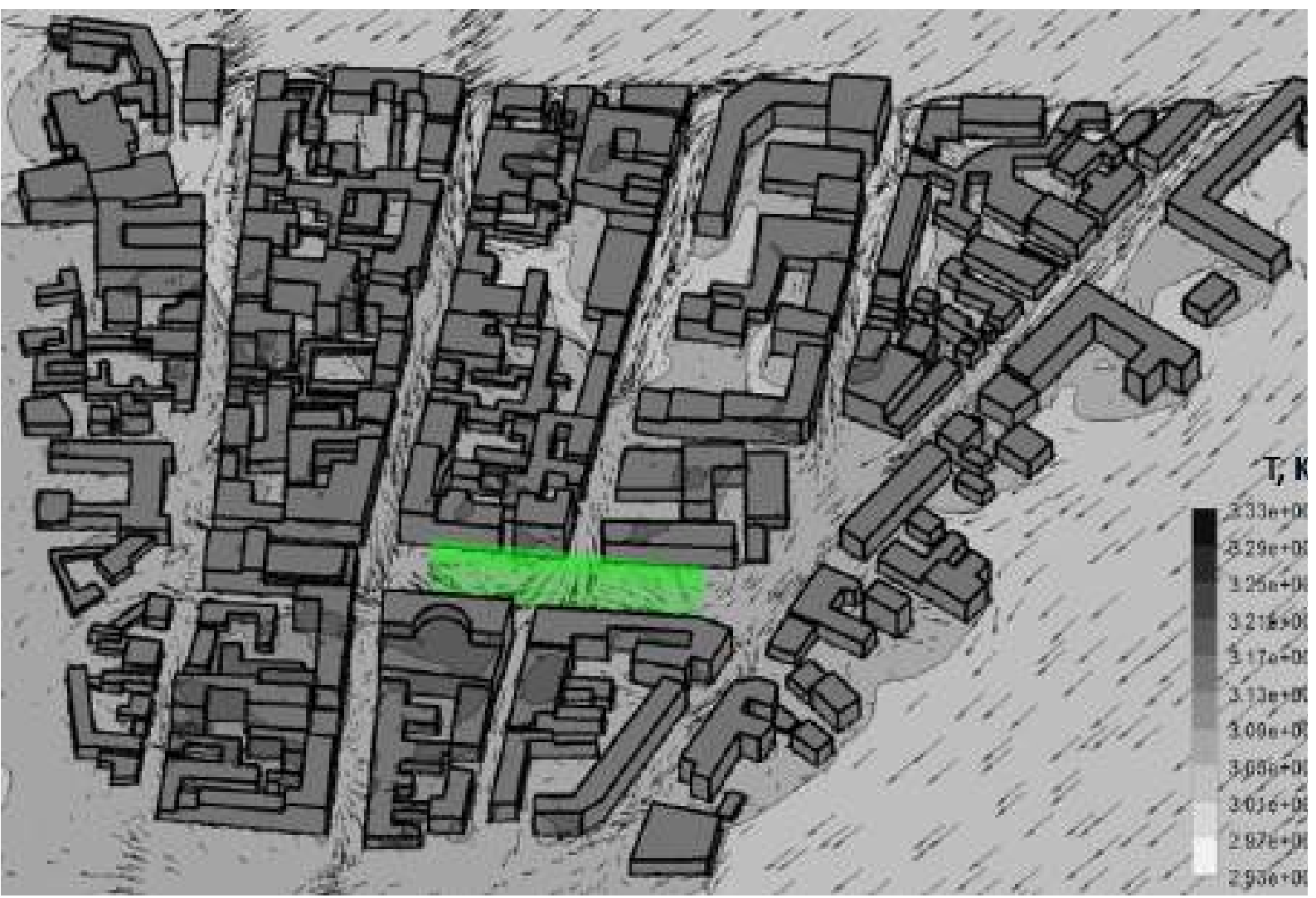

Fig. 6. Distribution of air temperature near the surface of buildings and soil at root mean square averaging over a period of 0,5 hours of daytime at elevated air temperature (northeast wind)

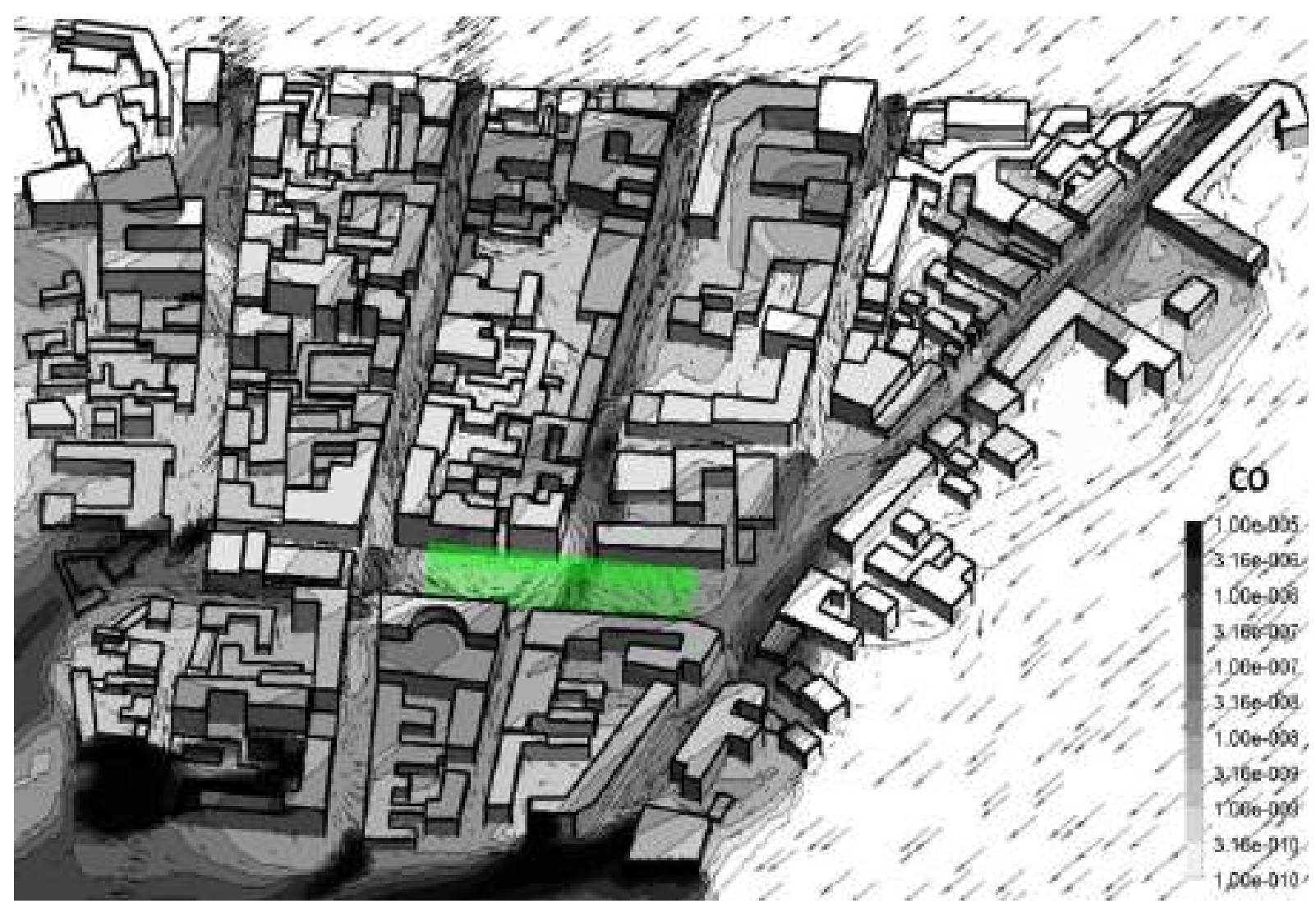

Fig. 7. Distribution of mass fraction of CO near the surface of buildings and soil at root mean square averaging over a period of 0,5 hours of daytime at elevated $\mathrm{T}$ of air (northeast wind) 


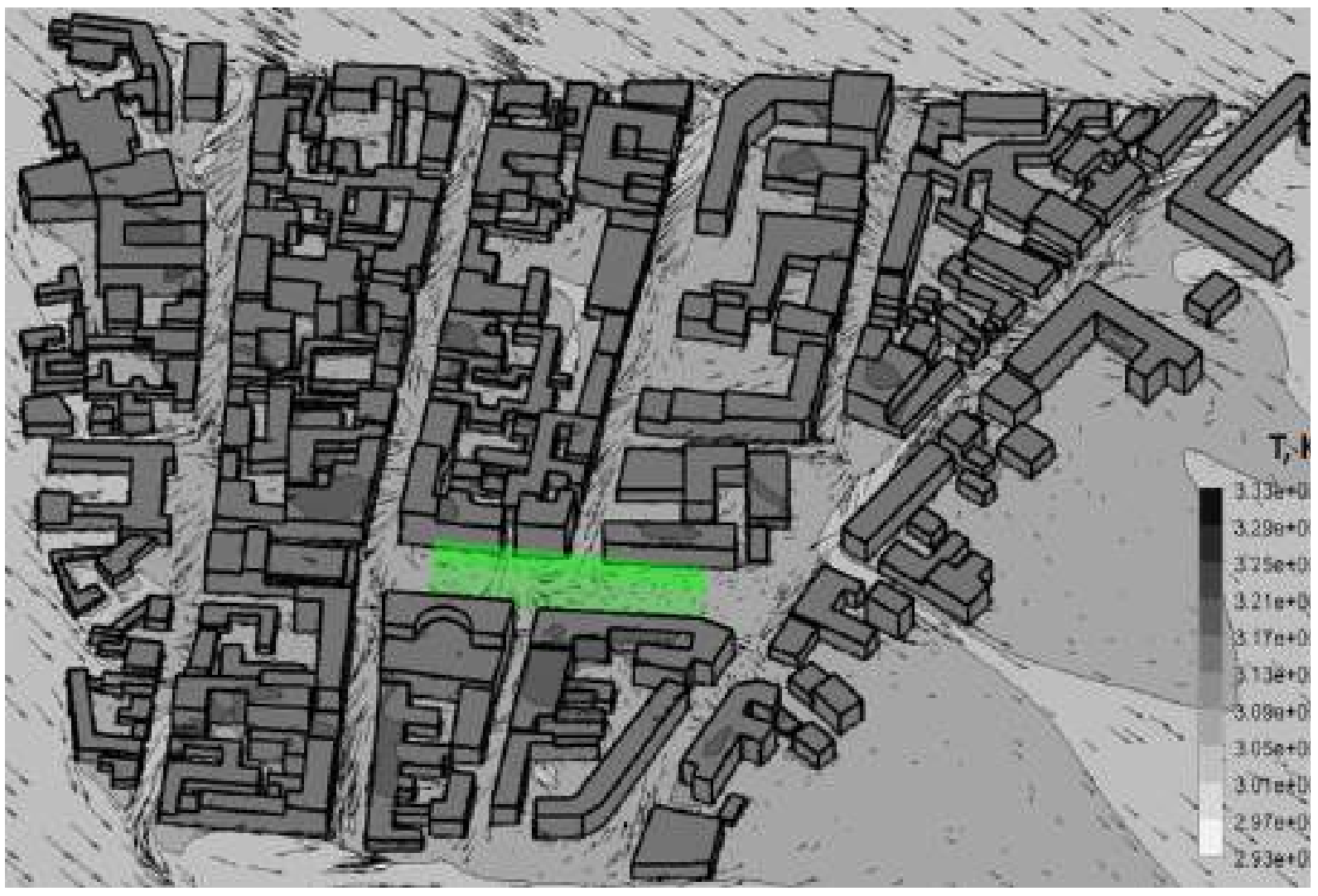

Fig. 8. Distribution of air temperature near the surface of buildings and soil at root mean square averaging over 0,5 hours of daytime with elevated $\mathrm{T}$ of air (northwest wind)

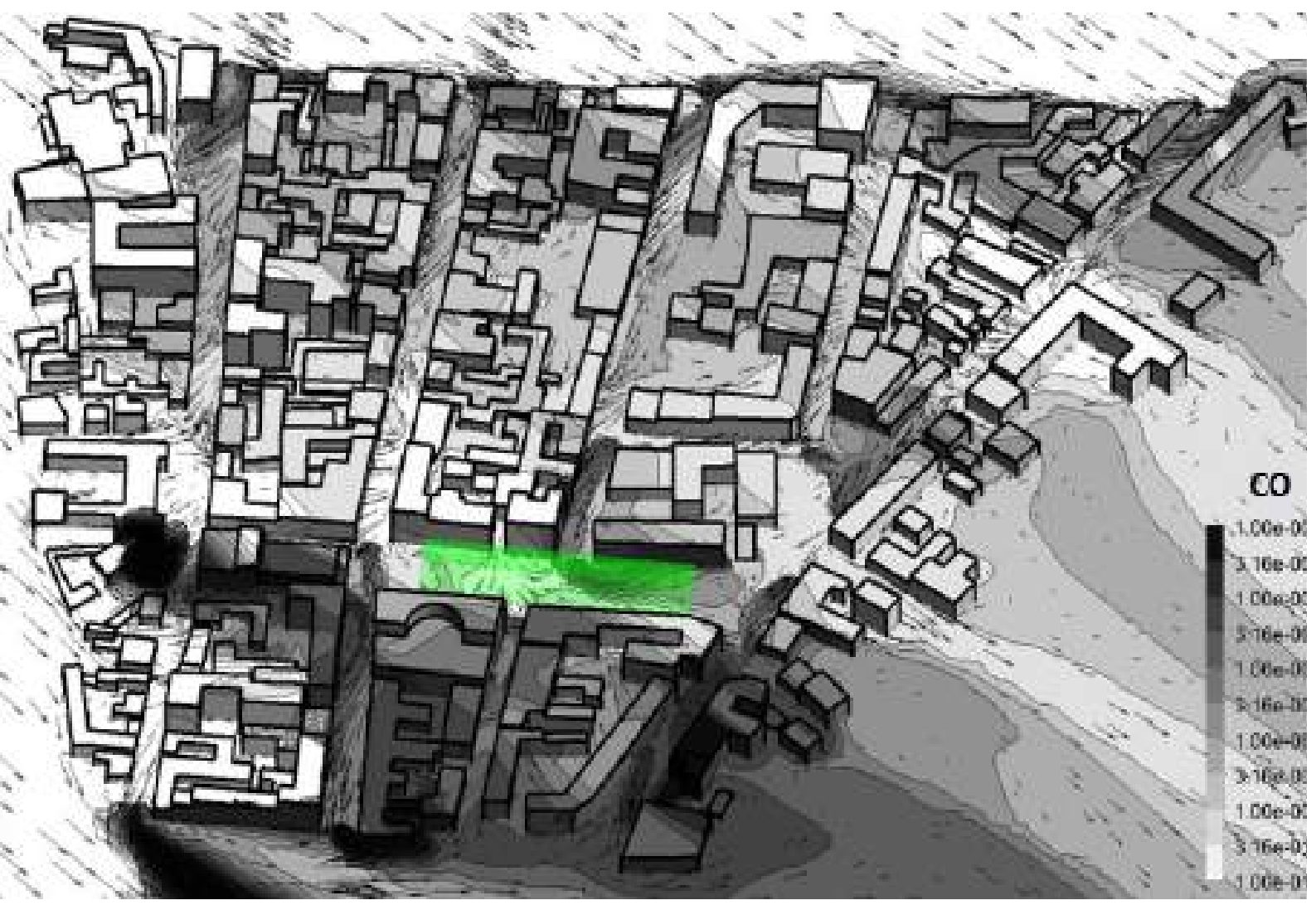

Fig. 9. Distribution of mass fraction of $\mathrm{CO}$ near the surface of buildings and soil at root mean square averaging over a period of 0,5 hours of daytime with high $\mathrm{T}$ of air (northwest wind) 


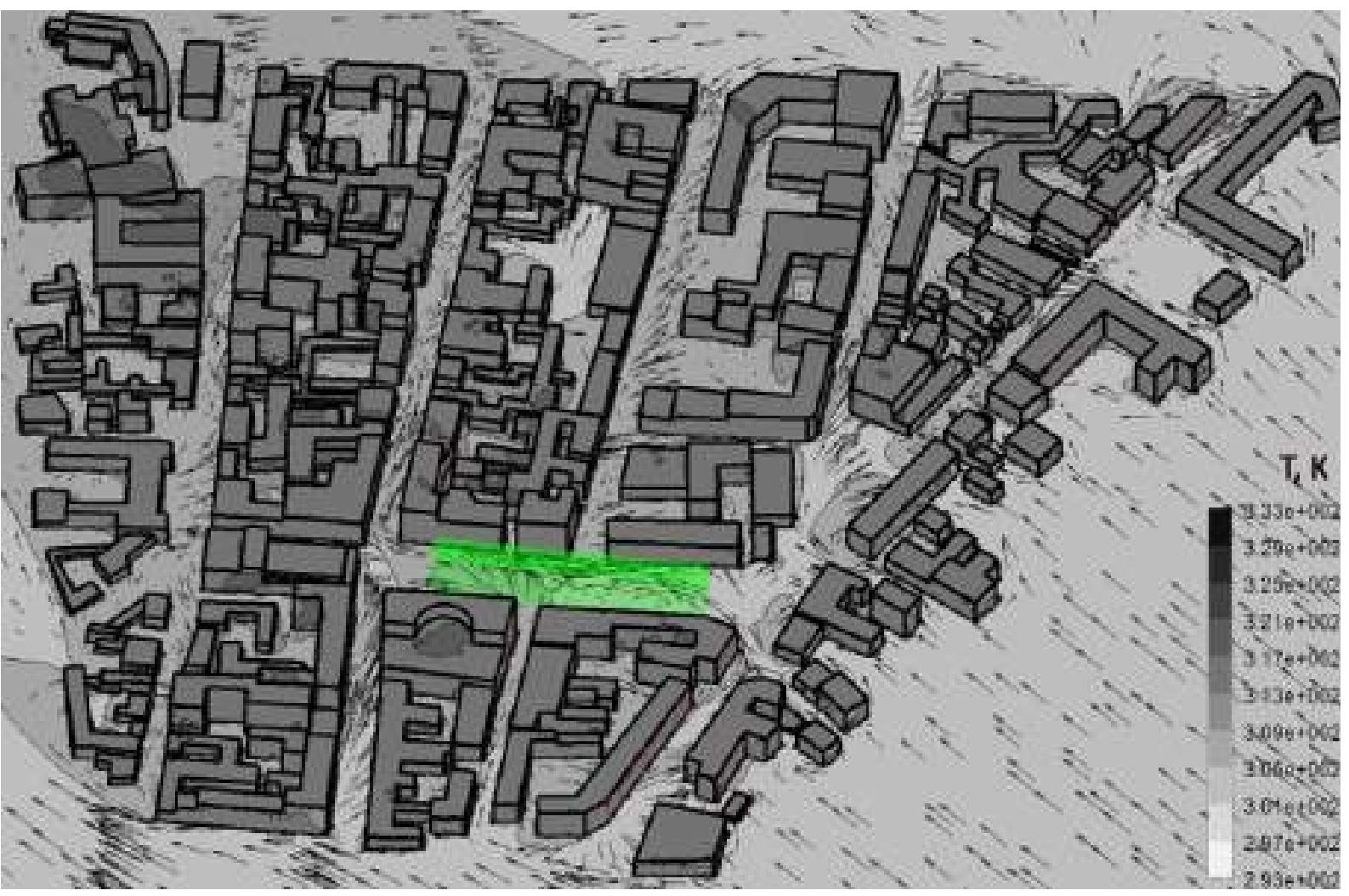

Fig. 10. Distribution of air temperature near the surface of buildings and soil at root mean square averaging over a period of 0,5 hours of daytime at elevated $\mathrm{T}$ air (south-east wind)

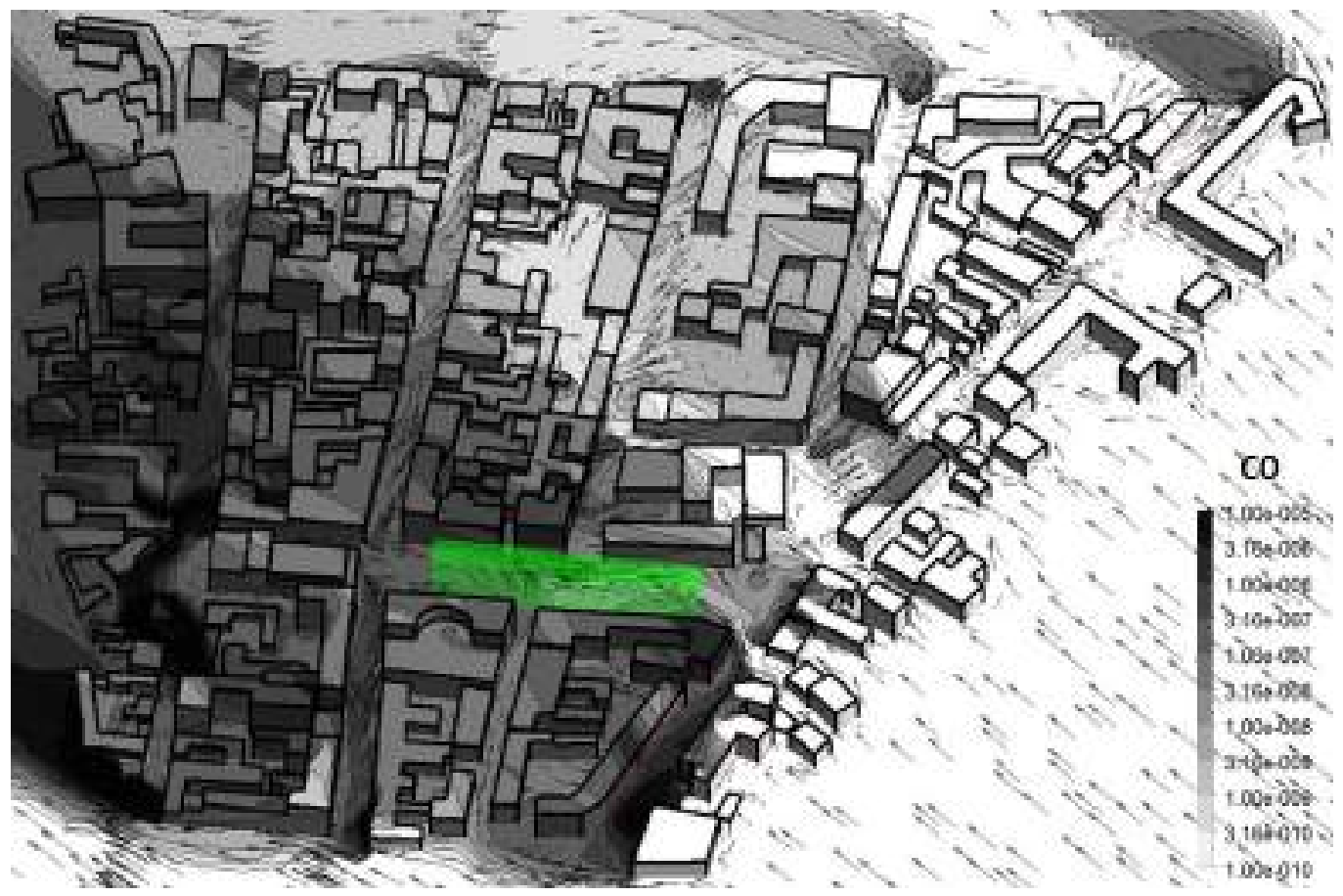

Fig. 11. Distribution of mass fraction of $\mathrm{CO}$ near the surface of buildings and soil at root mean square averaging over a period of 0,5 hours of daytime at elevated $\mathrm{T}$ of air (south-east wind) 
The main mass transfer in the considered areas is due to advection, so the closed space of urban development in some places is characterized by a relatively low concentration of $\mathrm{CO}$. Temperature distributions are also generally provided by advection, so the temperature of the windward walls of buildings is lower than the leeward ones.

The surface of the roofs is exposed to the heat flux of solar radiation, so the temperature of the roofs is slightly increased.

Figures 13-17 show graphs of the distribution of mass fraction of $\mathrm{CO}$, temperature and wind speed near the surface of the soil at a mean square averaging over a period of $0,5 \mathrm{~h}$ of daytime at elevated air temperature (southwestern wind) along the center line of streets № 2-5. The red frame highlights a wide gap in the houses between streets № 3-5, which houses a square with tall trees. The height of the trees in the garden reaches the height of the houses.

Almost all streets of the selected fragment of the central part of the city belong to the type of canyon streets with a characteristic parameter $\mathrm{K}=\mathrm{H} / \mathrm{W}$, where $\mathrm{H}$ is the height of the houses, $\mathrm{W}$ - the width of the street, which for the central streets № $2-6$ is $0,8 \ldots 1,0$. Fig. 12, 20, 21 show the current lines in the wind velocity fields for the southwestern wind case. It is possible to see screw forms of current lines along streets № 25 , despite the bevel angle of about 45 degrees of the velocity vector with respect to the directions of the centerlines of streets № 2-5. This flow pattern somewhat helps to cool down the walls of buildings and even out the concentration of impurities in the city center.

The calculations compared the effect of the presence of green space on the example of a square in the central part of the fragment. Comparisons of flow structure and transport in the presence or absence of trees in the square is shown in Fig. 17-22. Narrow, one-way, lowintensity streets pass between the square and the houses. That is, the space between the square and the houses can be considered as a canyon with parameter $\mathrm{K}=1,5$. Based on the analysis of the transfer through the square, it can be stated that in the southwestern wind most of the air in the presence of trees passes along narrow streets (Fig. 19-21).

It should be noted that there is a sharp nonuniformity in the transverse distribution of the mass fraction of $\mathrm{CO}$ for streets that flow at an angle between the centerline and the wind. This is the effect of the canyon streets, which can be seen in Fig. 5-11.

a

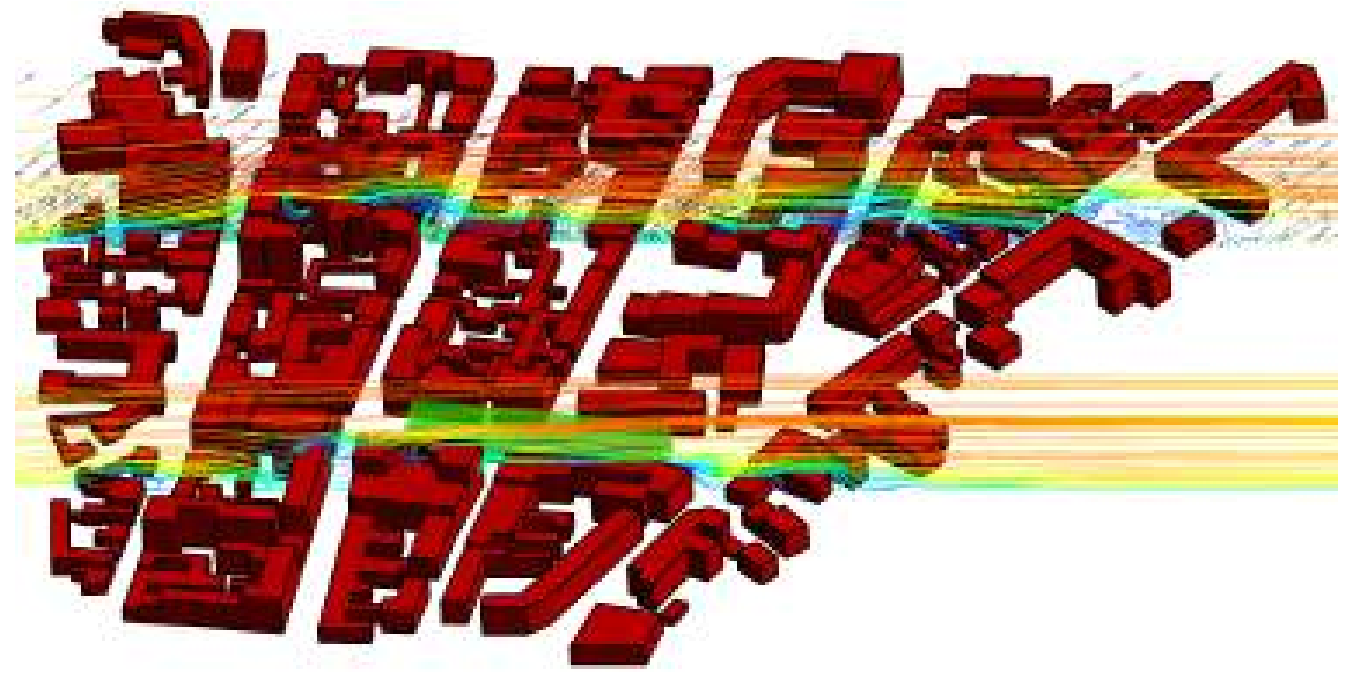

b

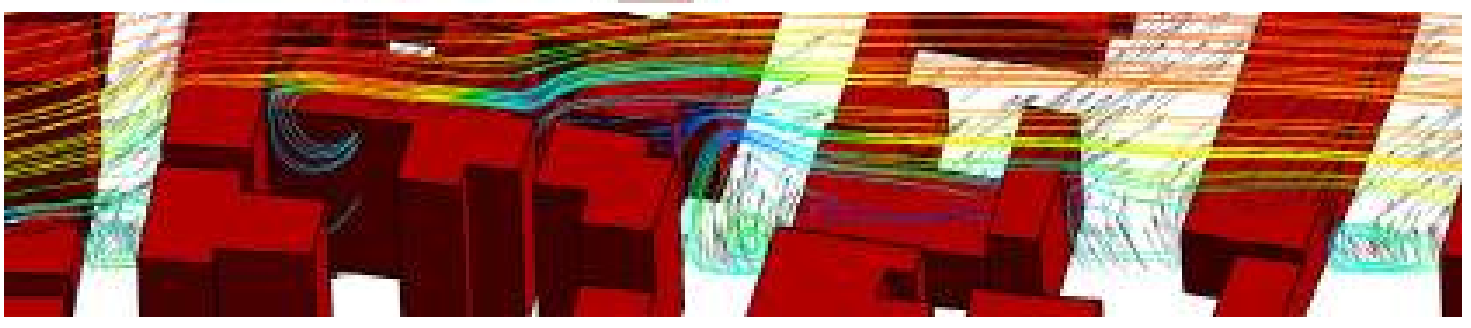

Fig. 12. Structure of the flow (canyon effect) and the current line in the projection on the plane in the color gamut of the speed of the CO component $(0-2 \mathrm{~m} / \mathrm{s})$ at the root mean square averaging over a period of 0,5 hours of daytime at elevated $\mathrm{T}$ air (southwest wind); a) - the central part; $b$ ) - fragment 

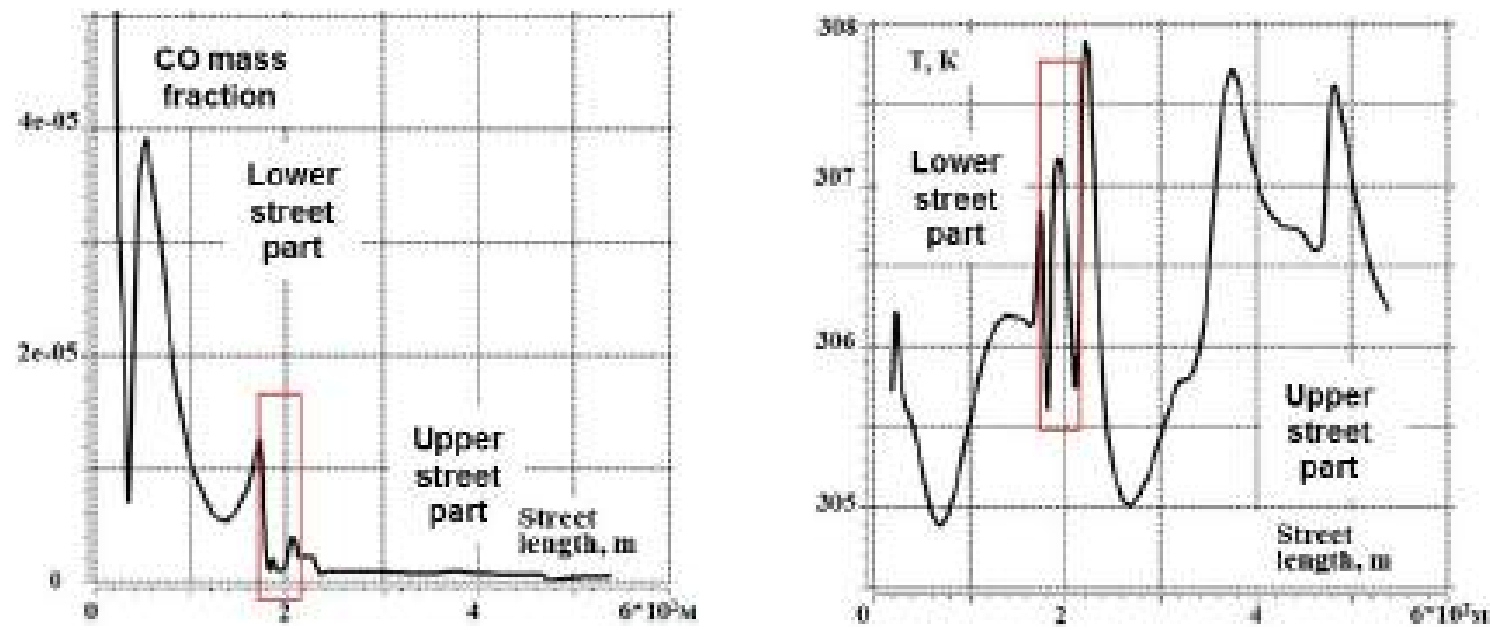

Fig. 13. Distribution of mass fraction of $\mathrm{CO}$ and temperature near the surface of the soil at root mean square averaging over a period of $0,5 \mathrm{~h}$ of daytime at elevated air temperature (southwest wind) along the centerline of street № 3; The wide gap in the layout of the houses where there is a square with tall trees is highlighted in red
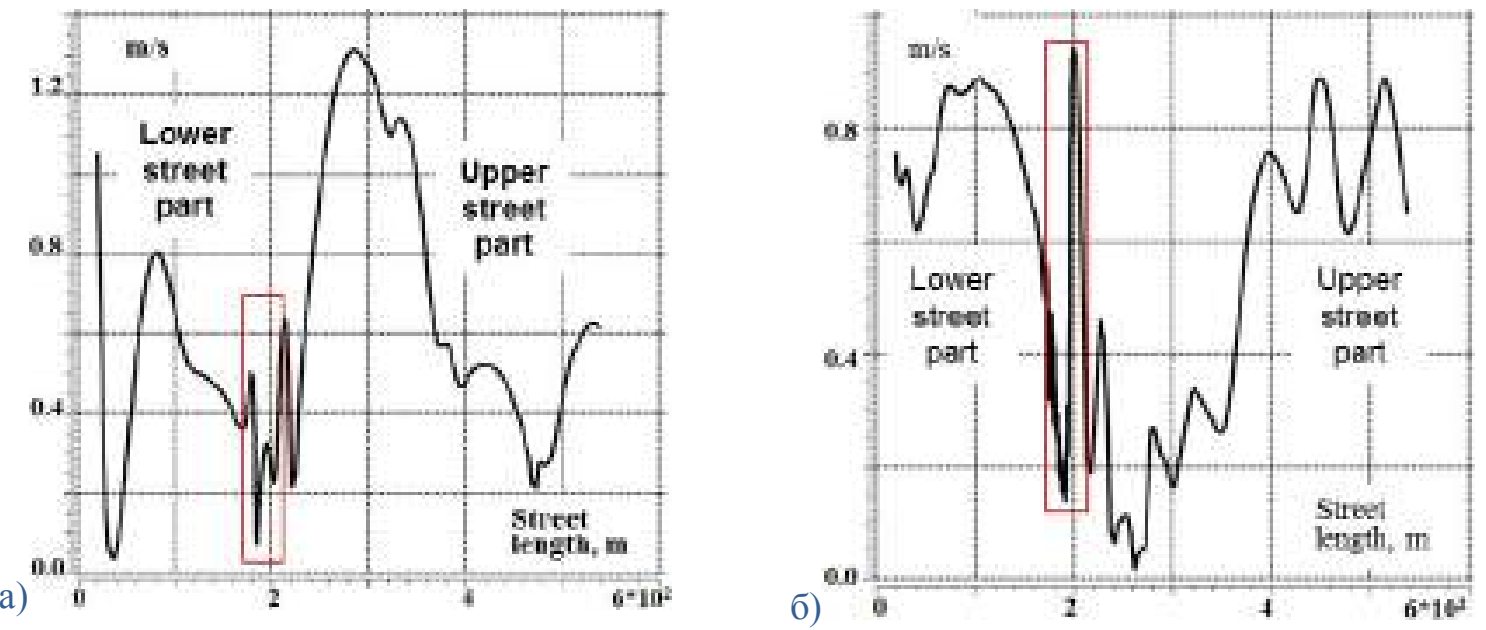

Fig. 14. Air velocity distribution near the surface of the soil at root mean square averaging over a period of 0,5 hours of daytime at elevated air temperature (southwestern wind) along the center line a) - for street № 3; b) - for street № 4
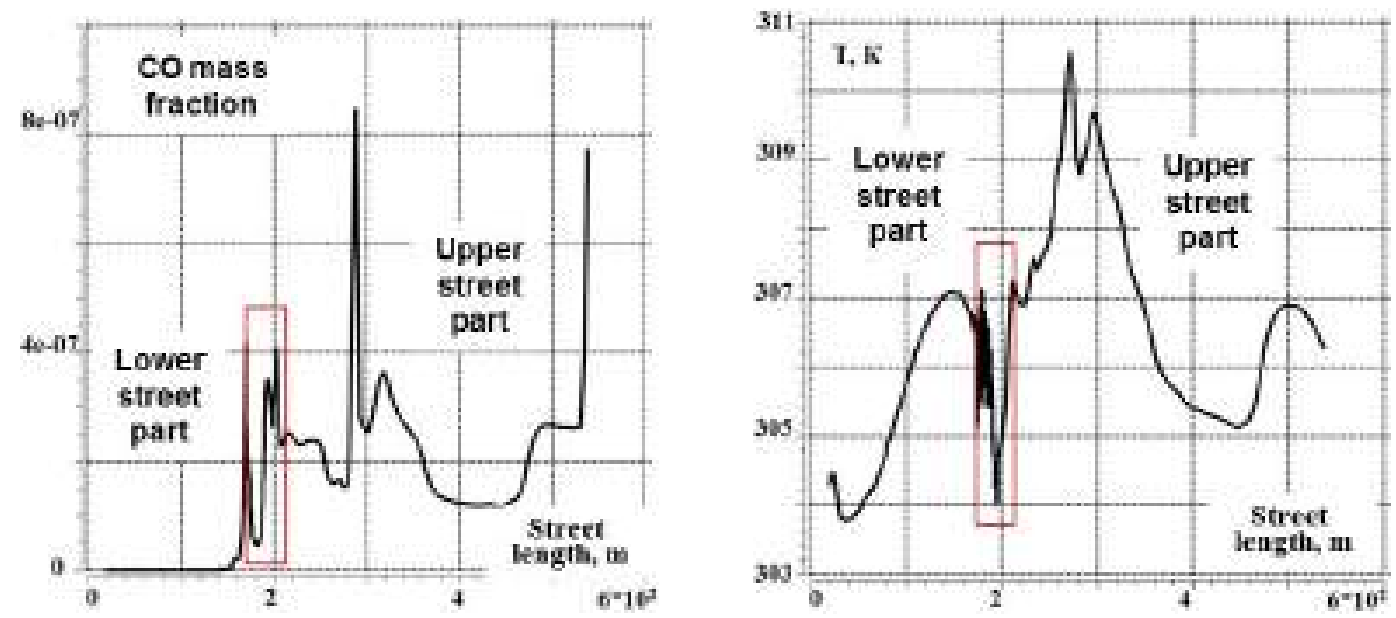

Fig. 15. Distribution of mass fraction of $\mathrm{CO}$ and temperature near the surface of the soil at root mean square averaging over a period of $0,5 \mathrm{~h}$ of daytime at elevated air temperature (southwestern wind) along the centerline of street № 4 

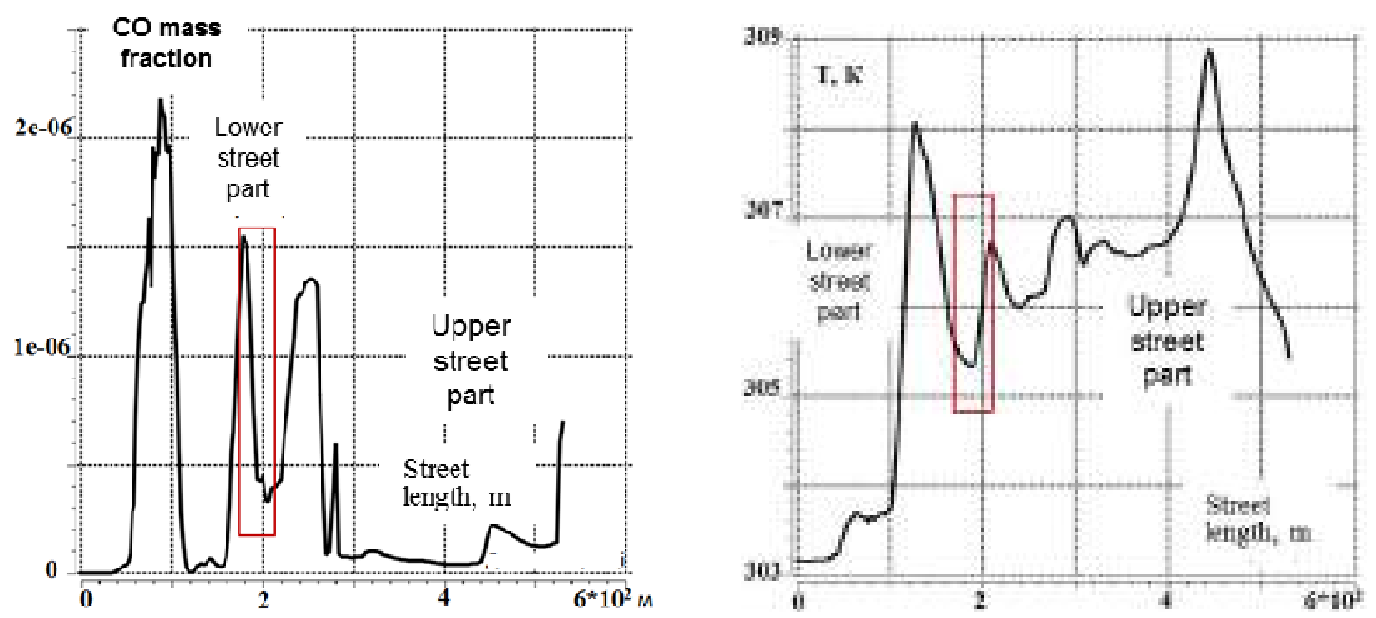

Fig. 16. Distribution of mass fraction of $\mathrm{CO}$ and temperature near the soil surface at root mean square averaging over a period of 0,5 hours of daytime at elevated air temperature (southwestern wind) along the centerline of street № 5
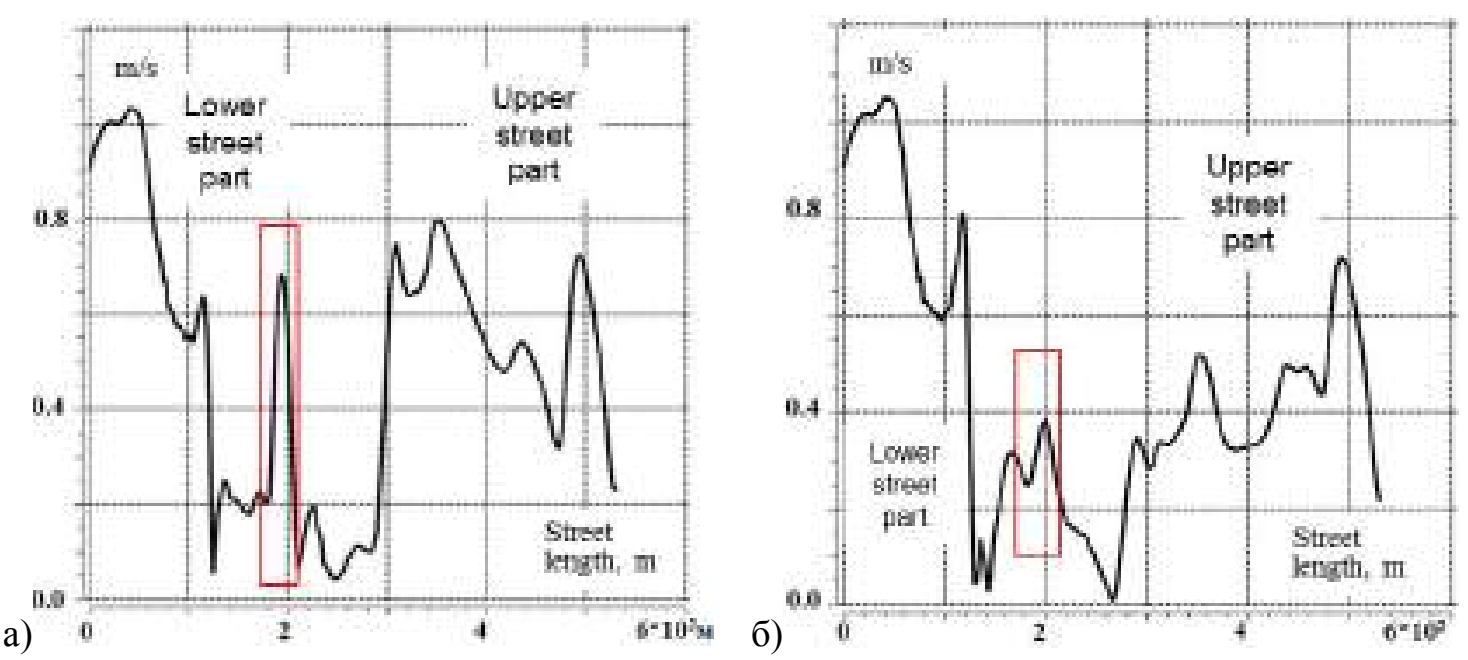

Fig. 17. Air velocity distribution near the surface of the soil at root mean square averaging over a period of 0,5 hours of daytime at elevated air temperature (southwestern wind) along the center line of street № 5 ; a) in the absence of trees in the square; b) in the presence of trees
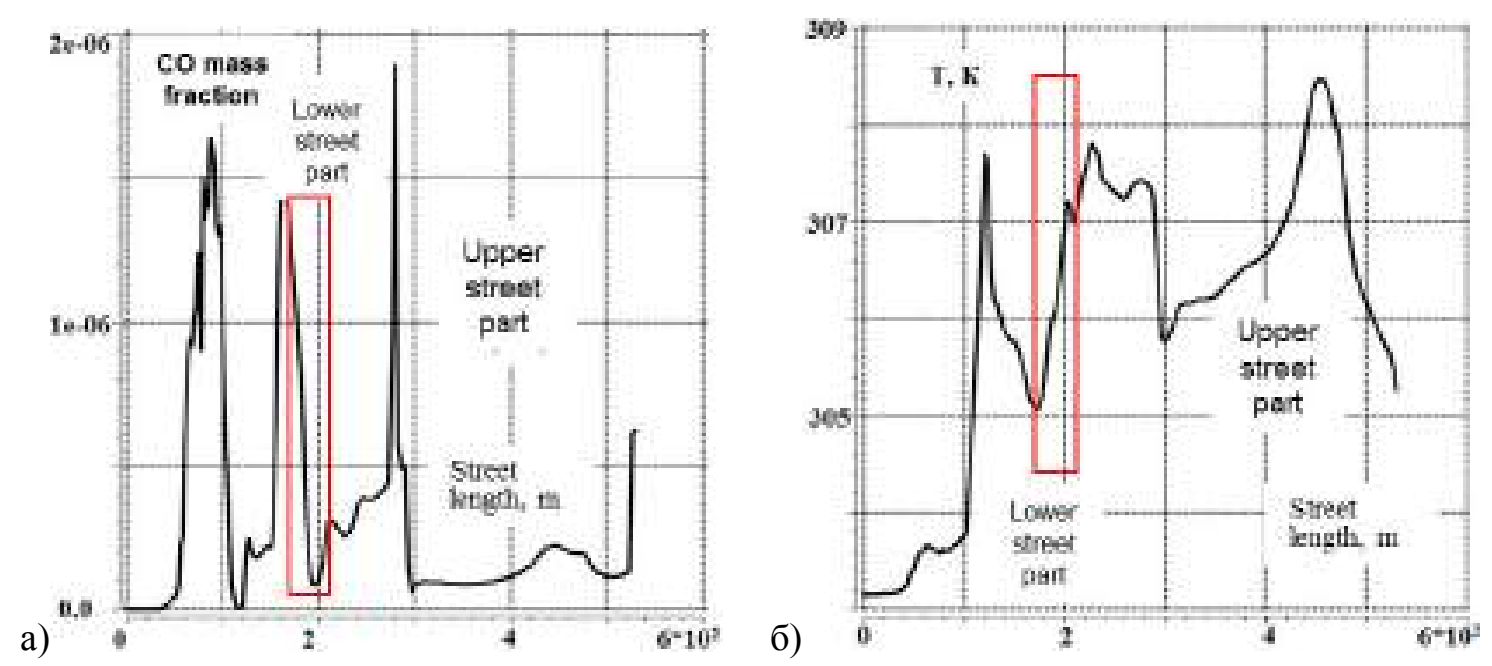

Fig. 18. Distribution of mass fraction of CO (a) and temperature (b) of air near the surface of the soil at a root mean square averaging over a period of $0 ? 5 \mathrm{~h}$ of daytime at elevated air temperature (southwestern wind) along the centerline of street № 5 in the absence of trees in the square 
a)

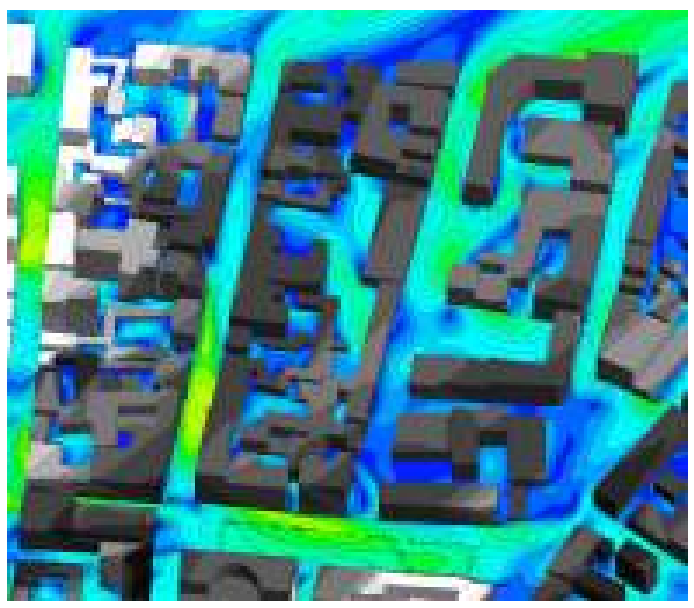

б)

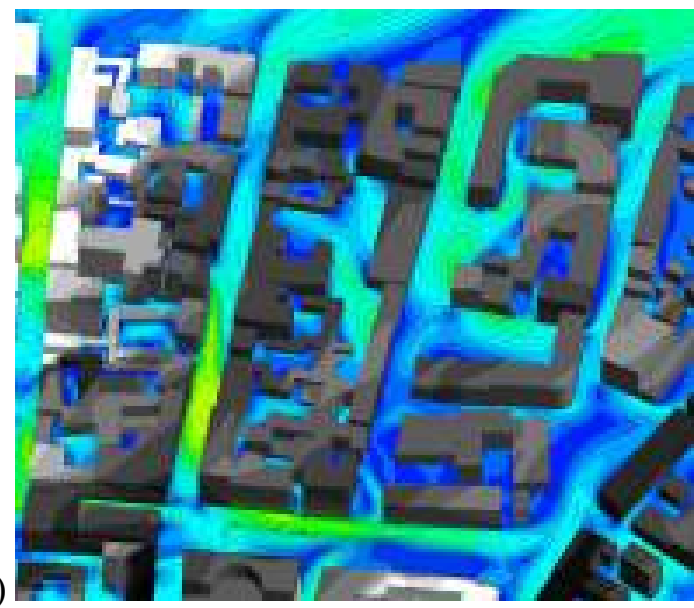

Fig. 19. Comparison of time-averaged fields of wind speed in the absence of trees in the square (a), in the presence of trees (b); wind is measured in the range $0-2 \mathrm{~m} / \mathrm{s}$; the walls and roofs of buildings reflect the mass fraction of $\mathrm{CO}$ in the range $1 \mathrm{e}-5-1 \mathrm{e}-10$; height of measuring points $-2 \mathrm{~m}$

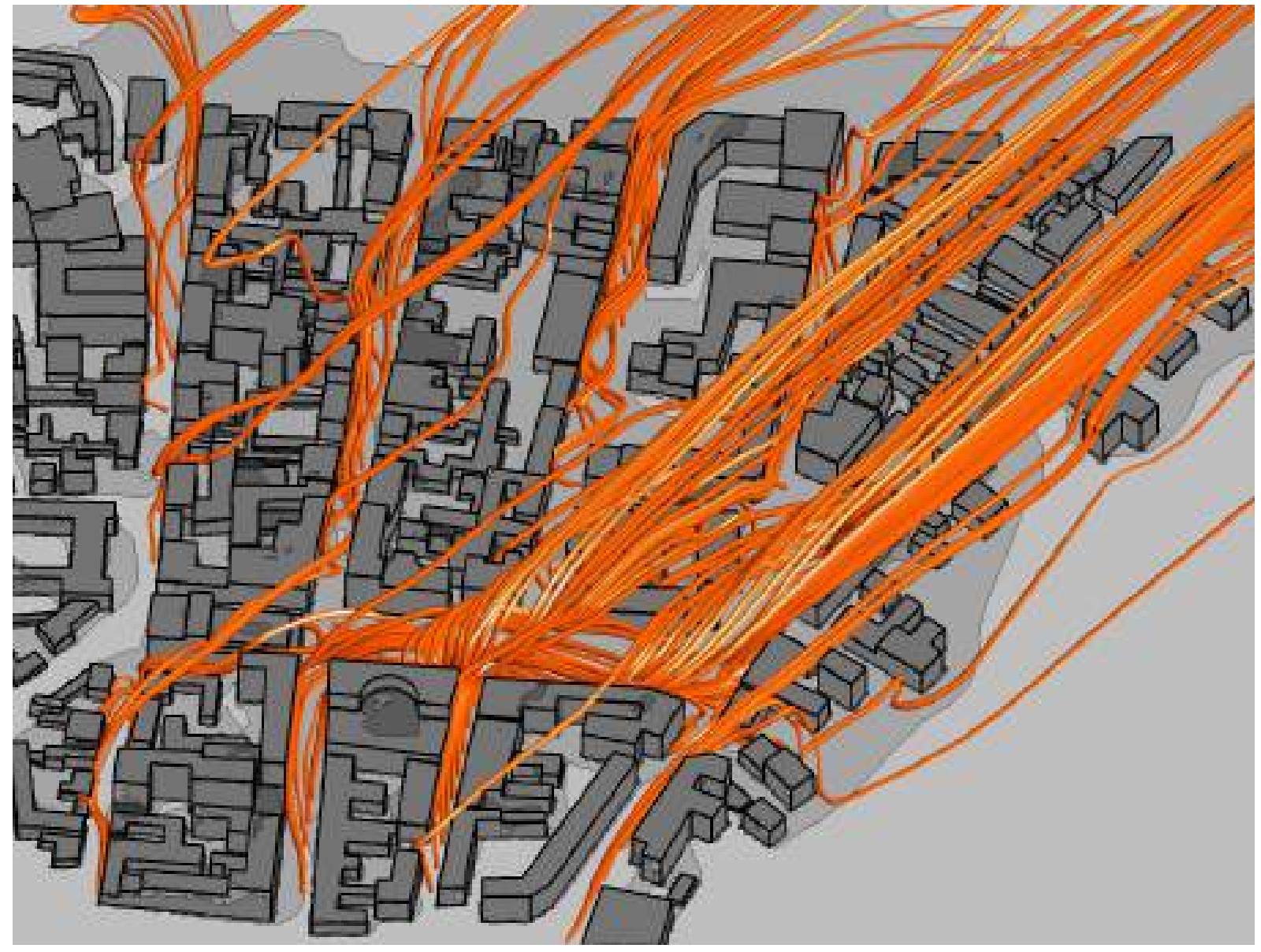

Fig. 20. Current lines of wind speed fields in the absence of trees in the square 


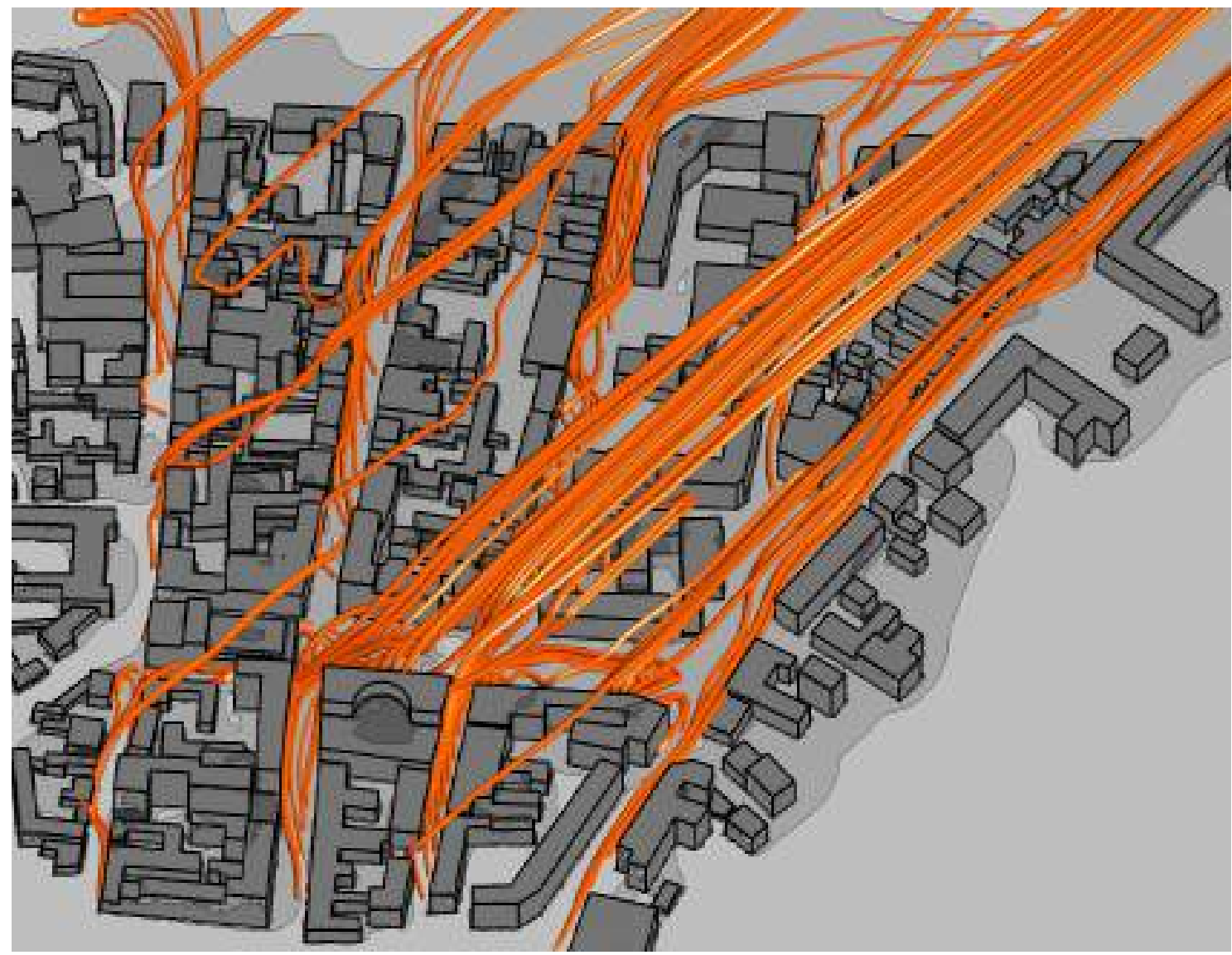

Fig. 21. Current lines of wind speed fields in the presence of trees in the square

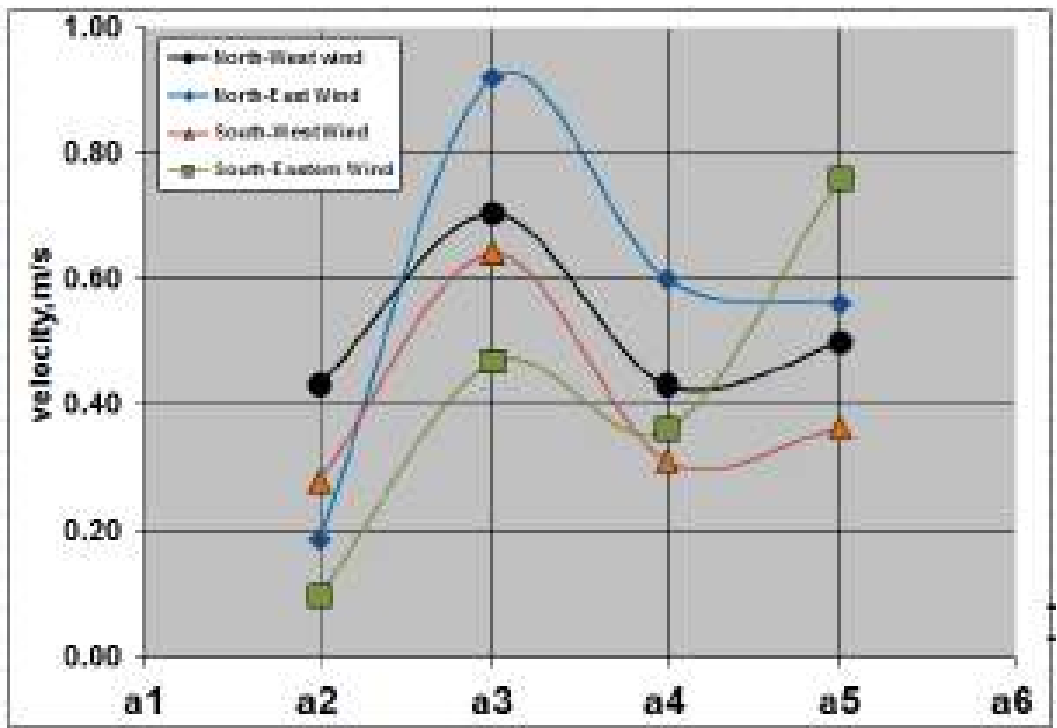

Fig. 22. Averaged values of air velocity at the crossroads a2-a5 near the soil surface at elevated air temperature depending on the wind direction 


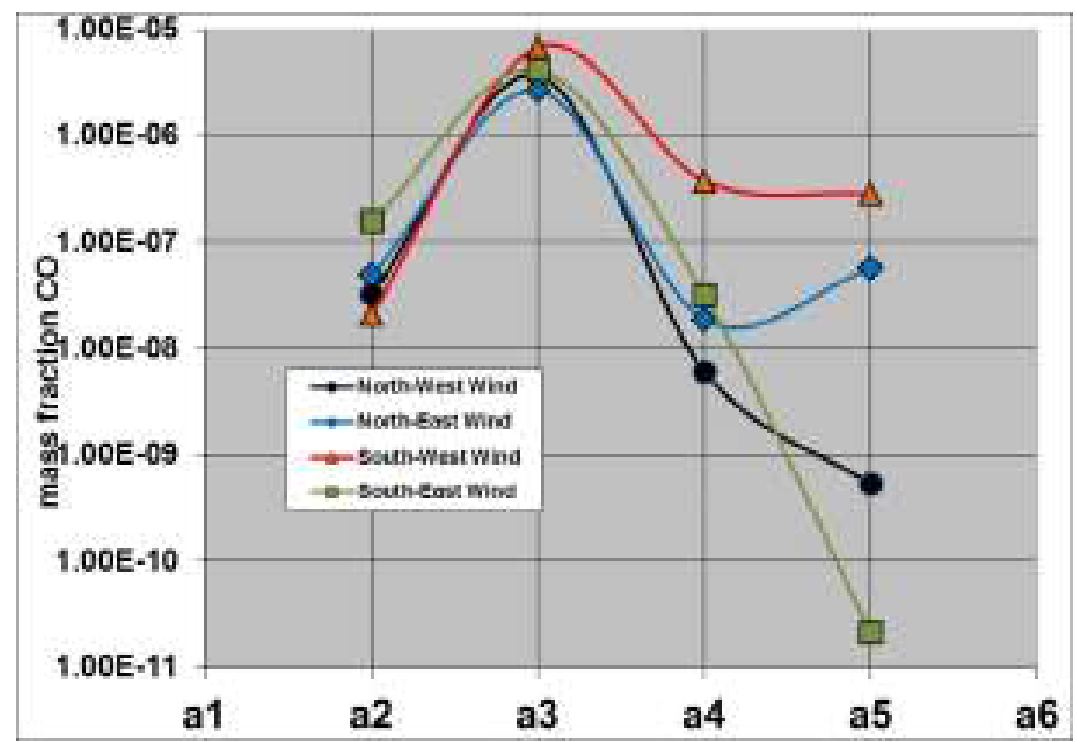

Fig. 23. Averaged values of the mass fraction of $\mathrm{CO}$ at the crossroads a2-a5 near the soil surface at elevated air temperature, depending on the wind direction

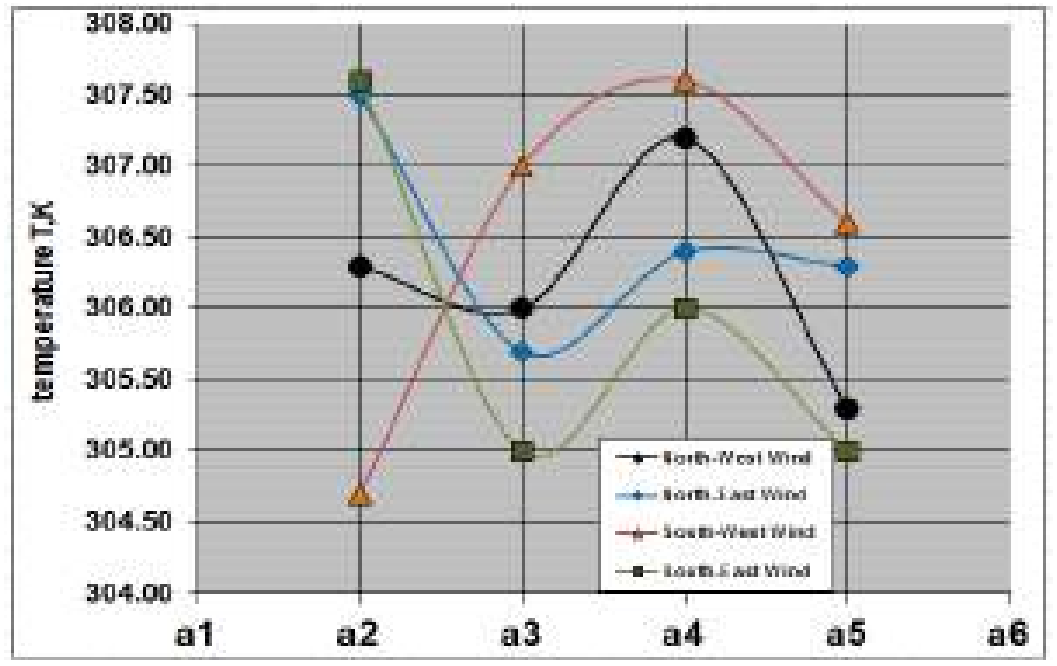

Fig. 24. Averaged values of air temperature at the crossroads a2-a5 near the soil surface at elevated air temperature depending on wind direction

The absence of trees changes the structure of the stream, the distribution of the concentration of $\mathrm{CO}$ and the temperature in the northern part of streets № 4, 5, 6. This can also be seen from the comparison of the air velocity distribution graphs near the soil surface along the centerline of street № 5 (Fig. 17-21).

Fig. 22-24 show the averaged values of the air parameters at the crosses № $2 \mathrm{a}-5 \mathrm{a}$ near the surface of the soil at elevated air temperature, depending on the wind direction. The selected intersections are internal to this fragment of the central part of the city, and therefore the effect of the boundary conditions on them is somewhat reduced. Also noteworthy is the similarity of the behavior of the parameters - $\mathrm{CO}$, flow velocity and, to a lesser extent, temperature, regardless of the direction of wind load. This indicates the dominant influence of city development on the dispersion of the impurity over the wind direction. It should be noted that the calculated concentration of $\mathrm{CO}$ correlates with the data obtained in [23].

\section{Conclusions}

The numerical model of building of the central part of the city of Kharkov in the near-Earth layer of the atmosphere is considered, taking into account the variable terrain of the adjacent terrain, taking into account the transfer of impurities in the conditions of a lateral wind plot and plantations of different density. On the example of this development, the existence of the effect of «heat island» is registered. 
The presence of plantations in the square has a local influence on the spread of CO. Along the street № 3, the concentration of $\mathrm{CO}$ and the temperature are almost the same; the air velocity is slightly increased in the case of the absence of trees in the garden, within $10 \%$. This is more pronounced at the bottom of the street.

The example of blowing up a residential district of a center shows the predominant influence of city development on the impurity dispersion compared to the effect of wind direction.

The results obtained indicate that a decrease in velocity in the porous green space and further weakening of the dispersion within the canyon can potentially have an undesirable effect on air quality.

\section{Literature}

1. Vardoulakis Sotiris, Bernard E.A. Fisher, Koulis Pericleous, Norbert Gonzalez-Flesca. Modeling air quality in street canyons: a review. Atmospheric Environment. 2003. 37: 155182.

2. Watson I. D., Johnson, G.T. Graphical estimation of sky view-factors in urban environments. Journal of Climatology. 1987. 7 (2): $193-$ 197.

3. Nunez M., Oke T.R. The Energy Balance of an Urban Canyon. Journal of Applied Meteorology. 1977. 16: 11-19.

4. Lien F.S., Yee E., Cheng Y. Simulation of mean flow and turbulence over a 2D building array using high-resolution CFD and a distributed drag force approach. Journal of Wind Engineering and Industrial Aerodynamics. 2004. 92: 117-158.

5. Kastner-Klein P., Fedorovich E., Rotach M.W. A wind-tunnel study of organized and turbulent air motions in urban street canyons. Journal of Wind Engineering and Industrial Aerodynamics. 2001. 89: 849-861.

6. Oke T.R. Street design and urban canopy layer climate. Energy and Buildings. 1988. 11: 103113.

7. Kim J.J., Baik J.J. A numerical study of thermal effects on flow and pollutant dispersion in urban street canyons. Journal of Applied Meteorology. 1999. 38: 1249-1261.

8. Kovar-Panskus A. Influence of geometry on the mean flow within urban street canyons A comparison of wind-tunnel experiments and numerical simulations. Urban Air Quality - Recent Advances, Proceedings. 2002. 365-380.

9. Addepalli B., Pardyjak E. Investigation of the Flow Structure in Step-Up Street Canyons-Mean Flow and Turbulence Statistics. Boundary-Layer Meteorology. V. 148. 2013. P. 133-155.

10. Kastner-Klein P., Berkowicz R., Britter R. The influence of street architecture on flow and dispersion in street canyons. Meteorology and Atmospheric Physics. 2004. 87: 121-131.
11. Pol S.U., Brown M. Flow Patterns at the Ends of a Street Canyon: Measurements from the Joint Urban 2003 Field Experiment. Journal Of Applied Meteorology And Climatology. 2008. 47.

12. Spatial and temporal characterization of traffic emissions in urban microenvironments with a mobile laboratory / L. Pirjola Atmospheric Environment. 2012. 63: 156.

13. Optimization of tree canopy model for CFD application to local area wind energy prediction / A. Mochida and other. NATO ASI 980064. Flow and Transport Processes in complex obstructed geometries. May 4-15, 2004, IHM NAS, Kyiv, Ukraine. P. 139-141.

14. Emission and dispersion modeling of Lisbon air quality at local scale / C. Borrego and other. Atmospheric Environment, 2003. Vol. 37. P. 51975205.

15. Солодов В.Г., Стародубцев Ю.В. Научноприкладной программный комплекс $\mathrm{MTFS}^{\circledR}$ для расчета трехмерных вязких турбулентных течений жидкостей и газов в областях произвольной формы. Сертификат гос. регистр. авт. прав, УГААСП. № 5921. 07.16.2002.

16. Thykier-Nielsen S., Roed J. Dispersion as consequence of a detonation of a dirty bomb in an urban area. NKS Conference on «Radioactive contamination in urban areas», Riso, Roskilde, Denmark. May 7-9. 2003. P. 135.

17. CFD prediction of flow over complex terrain using Local Area Wind Energy Prediction System (LAWEPS) / S. Murakami, and other. Proc. of $11^{\text {th }}$ Int. Conf. On Wind Engineering, Texas. Vol. 2. 2003. P. 2821-2828.

18. Gayev Editors Ye., Hunt J. Flow and transport with complex Obstructions. Applications to Cities. Vegetative Canopies and Industry. Springer Publ. 2007. 414 p.

19. Математичне моделювання забруднення атмосферного повітря придорожнього простору / В.Г. Солодов та ін. Автошляховик України. 2009. № 3. C. 42-47.

20. Солодов В. Г., Авершин А.Г. Модель переноса атмосферных загрязнений в полосе насаждений возле автомобильной дороги. Автомобиль и электроника. Современные технологии. 2018. Вып. 13. С. 98-107.

21. Солодов В.Г. Моделирование турбулентности. Расчет больших вихрей. Харків: ХНАДУ, $2011.167 \mathrm{c}$.

22. Варгафтик В. Б. Справочник по теплофизическим свойствам газов и жидкостей. Москва: Наука, 1972. 720 с.

23. Говорущенко Н.Я., Филиппов В.В., Величко Г.В. Проблемы и методы оценки экологического и энергетического качества автомобильных дорог. Автоматизированные технологии CREDO’2000. C. 45-51.

\section{References}

1. Vardoulakis Sotiris, Bernard E.A. Fisher, Koulis Pericleous, Norbert Gonzalez-Flesca. 
Modeling air quality in street canyons: a review. Atmospheric Environment. 2003. 37: 155182.

2. Watson I. D., Johnson, G.T. Graphical estimation of sky view-factors in urban environments. Journal of Climatology. 1987. 7 (2): 193-197.

3. Nunez M., Oke T.R. The Energy Balance of an Urban Canyon. Journal of Applied Meteorology. 1977. 16: 11-19.

4. Lien F.S., Yee E., Cheng Y. Simulation of mean flow and turbulence over a 2D building array using high-resolution CFD and a distributed drag force approach. Journal of Wind Engineering and Industrial Aerodynamics. 2004. 92: 117-158.

5. Kastner-Klein P., Fedorovich E., Rotach M.W. A wind-tunnel study of organized and turbulent air motions in urban street canyons. Journal of Wind Engineering and Industrial Aerodynamics. 2001. 89: 849-861.

6. Oke T.R. Street design and urban canopy layer climate. Energy and Buildings. 1988. 11: 103113.

7. Kim J.J., Baik J.J. A numerical study of thermal effects on flow and pollutant dispersion in urban street canyons. Journal of Applied Meteorology. 1999. 38: 1249-1261.

8. Kovar-Panskus A. Influence of geometry on the mean flow within urban street canyons A comparison of wind-tunnel experiments and numerical simulations. Urban Air Quality - Recent Advances, Proceedings. 2002. 365-380.

9. Addepalli B., Pardyjak E. Investigation of the Flow Structure in Step-Up Street Canyons-Mean Flow and Turbulence Statistics. Boundary-Layer Meteorology. V. 148. 2013. P. 133-155.

10. Kastner-Klein P., Berkowicz R., Britter R. The influence of street architecture on flow and dispersion in street canyons. Meteorology and Atmospheric Physics. 2004. 87: 121-131.

11. Pol S.U., Brown M. Flow Patterns at the Ends of a Street Canyon: Measurements from the Joint Urban 2003 Field Experiment. Journal Of Applied Meteorology And Climatology. 2008. 47.

12. Spatial and temporal characterization of traffic emissions in urban microenvironments with a mobile laboratory / L. Pirjola Atmospheric Environment. 2012. 63: 156.

13. Optimization of tree canopy model for CFD application to local area wind energy prediction / A. Mochida and other. NATO ASI 980064. Flow and Transport Processes in complex obstructed geometries. May 4-15, 2004, IHM NAS, Kyiv, Ukraine. P. 139-141.

14. Emission and dispersion modeling of Lisbon air quality at local scale / C. Borrego and other. Atmospheric Environment, 2003. Vol. 37. P. 51975205.

15. Application Software MTFS ${ }^{\circledR}$ for Calculation of 3D Viscous Turbulent Liquid and Gas Flows in Arbitrary Shape Domains, Certificate of State Registration, Ukrainian State Agency of Copyrights and Related Rights. № 5921. 07.16.2002.
16. Thykier-Nielsen S., Roed J. Dispersion as consequence of a detonation of a dirty bomb in an urban area. NKS Conference on «Radioactive contamination in urban areas», Riso, Roskilde, Denmark. May 7-9. 2003. P. 135.

17. CFD prediction of flow over complex terrain using Local Area Wind Energy Prediction System (LAWEPS) / S. Murakami, and other. Proc. of $11^{\text {th }}$ Int. Conf. On Wind Engineering, Texas. Vol. 2. 2003. P. 2821-2828.

18. Gayev Editors Ye., Hunt J. Flow and transport with complex Obstructions. Applications to Cities. Vegetative Canopies and Industry. Springer Publ. 2007. 414 p.

19. Matematiche modeluvannia zabrudnennia atmosfernogo povitria pridorojnogoo proctoru/ V. Solodov ta in. Avtoshlahovik Ukraini. 2009. № 3. P. 42-47.

20. Solodov V., Avershin A. The Model of Transfer of Atmosphere Pollution in Roadside Vegetation near the Highway. Automobile and Electronics. Modern Technologies. 2018. 13. S. 98-107.

21. Solodov V. Turbulent flow modeling. Large Eddy Simulation. Kharkiv: HNADU, 2011. 167 p.

22. Vargaftik V.B. Handbook of thermophysical properties of gases and liquids. Moskva: Nauka, 1972. $720 \mathrm{p}$.

23. Govorushenko N.Ya., Filippov V.V., Velichko G.V. Problemi i metodi otsenki ekologicheskogo i energeticheskogo kachestva avtomobilnix dorog. Avtomatizirovanie technologii CREDO'2000. P. 45-51.

Модель перенесення домішки транспортного походження в структурі вулиць-каньйонів центральної частини м. Харкова

Анотація. Робота присвячена розробленню моделі та дослідженню особливостей проиесу перенесення забруднювальних речовин у приземному шарі кварталів центральної частини міста за наявності насаджень $i$ рельєфу місиевості. Якоснова моделі розглядається мікрорайон иентральної частини м. Харкова. Цей мікрорайон $\epsilon$ підмоделлю загальної моделі центру міста, обмеженого яром, рікою і лісопарком. На иій основі застосований підхід LAWEP [17], щзо полягає в попередньому розрахунку адвекиії для загальної моделі центру на відносно грубій сітиі, потім перенесення даних як граничних умов $i$ початкового наближення на розглянутій підмоделі. Уздовж осьової лінії вулиць передбачається лінійне джерело, що виділяє постійну в часі витрату домішки. Домішка переноситься в приземному шарі вулиць в умовах бічної вітрової епюpu, змінного рельєфу місцевості та насаджень у вигляді скверу. Модель основана на сітковому описі тривимірної ділянки. Рух повітряного середовища описується рівняннями Нав'є-Стокса, усередненими за Рейнольдсом. Суцільне середовище приймається слабко стисливим, багатокомпонентним та хімічно нейтральним. Для моделювання турбулентних ефектів перенесення 
як базова використана високорейнольдсова двопараметрична диференціальна модель турбулентності з пристінними функиіями. Моделювання захаращення простору листям і гілками дерев виконується на основі моделі пористого середовища. Рівняння Нав'є-Стокса, а також рівняння перенесення для параметрів моделі турбулентності містять джерельні члени в правих частинах у вигляді статечної залежності модуля швидкості в ділянках пористості. Ця модель інтерпретує вплив рослинності як однорідний ізотропний опір малоінериійного об 'єму, додаткові члени в рівняннях моделі турбулентності збільшують виробництво турбулентності. Дослідження проведено з використанням авторського програмного комплексу MTFS®, в якому базовий неявний алгоритм забезпечений розщепленням за методом змінних напрямків $i$ TVD схемою 2/3-го порядку точності. Розрахунки виконані методом установлення перебігу від загальмованого стану. Перебіг у підмоделі розраховувався в нестаціонарній постановці за стаціонарних граничних умов протягом позарозрахункової ділянки вважалося повністю турбулентним, щзо визначалося вхідними граничними умовами. Вхідний профіль швидкості вітру використовувався з урахуванням прикордонного шару. Виконано моделювання поширення домішки вздовж кварталів підмоделі центру за наявності/відсутності листя у сквері. Отримано задовільний збіг з експериментальними даними. Виявлено явище теплового острова. Підтверджена вихрова структура ліній струму за умови обтікання вулиць-каньйонів. Показаний вплив структури вулищь-каньйонів на поширення домішки від транспортних засобів.

Ключові слова: структура вулиць-каньйонів, насадження, приземний шар, перенесення забруднень.

В.Г. Солодов, проф., д.т.н., Харківський національний автомобільно-дорожній університет, Україна, solodov.v@gmail.com
Модель переноса примеси транспортного происхождения в структуре улиц-каньонов центральной части г. Харькова

Аннотация. Работа посвящена разработке модели и исследованию особенностей процесса переноса загрязняющих веществ в приземном слое кварталов иентральной части города при наличии насаждений и рельефа местности. В качестве основы модели рассматривается микрорайон иентральной части города Харькова. Вдоль осевой линии улии предусматривается линейный источник, выделяющий постоянный во времени расход примеси. Примесь переносится в приземном слое улии в условиях боковой ветровой эпюpы, переменного рельефа местности и насаждений в виде сквера. Модель основана на сеточном описании данной трехмерной области. Движение воздушной среды описывается уравнениями Навье-Стокса, осредненныли по Рейнольдсу. Сплошная среда принимается слабо сжимаемой, многокомпонентной $i$ химически нейтральной. Для моделирования в качестве базовой использована высокорейнольдсовая двухпараметрическая дифференциальная модель турбулентности с пристенными функииями. Моделирование загромождений выполняется на основе модели пористой среды. Исследование проведено с использованием авторского программного комплекса MTFS $^{\circledR}$, на основе TVD схемы 2/3-го порядка точности. Выполнено моделирование распространения примеси вдоль кварталов подмодели центра при наличии/отсутствии листвы в сквере. Обнаружено явление теплового острова. Показано влияние структурь улиц-каньонов на распространение примеси от транспортных средств.

Ключевые слова: Структура улиц-каньонов, насаждения, приземный слой, перенос загрязнений.

В.Г. Солодов, проф., д.т.н., Харьковский национальный автомобильно-дорожный университет, Украина, solodov.v@gmail.com 